\title{
SERANGAN HAMA DEFOLIATOR PADA POLA TANAM MONOKULTUR DAN AGROFORESTRI JABON
}

\author{
Sri Utami ${ }^{1)}$ dan Agus Ismanto ${ }^{2)^{*}}$ \\ ${ }^{1)}$ Balai Penelitian Kehutanan Palembang \\ Jl. Kol. Burlian KM 6,5 Puntikayu Palembang \\ ${ }^{2)}$ Pusat Penelitian dan Pengembangan Hasil Hutan \\ Jl. Gunung Batu No. 5 Bogor \\ *e-mail: aismanto59@gmail.com
}

\begin{abstract}
Defoliator Pest Attack on Monoculture and Agroforestry Planting Patterns of Jabon
\end{abstract}

Jabon (Anthocephalus spp.) is one of the local plant species in Indonesia that have the potential to be developed in forest plantation as well as for other purposes, such as mined-land reclamation, reforestation and tree shade, because growth is very fast, the ability adaptation on various site conditions and silvicultural treatment is relatively easy. This species is also expected to become increasingly important to the timber industry in the future, especially when the raw material for construction timber from natural forests is to be on the wane. This plant has long time cultivated by society in almost all parts of Indonesia either by monoculture and mixture such as agroforestry. One of the obstacles of this type is their defoliator pests. This study aimed to identify the type of pest defoliator which attacking red Jabon (A. macrophyllus Roxb. Havil) and white Jabon (A. cadamba Miq.) 8 months aged were planted in monoculture or agroforestry (paddy-rice plants). The study was conducted on August to December 2014 in Sumber Mekar Mukti and Sukatani Village, Tanjung Lago Subdistrict, Banyuasin County, South Sumatera Province. The results showed that the types of pests that attack plant red Jabon was Moduza procris Cramer (Lepidoptera: Nymphalidae) with an attack percentage of $45.5 \%$. While on the plant, namely white Jabon was Arthroschista hilaralis Walk with an attack percentage of $86 \%$. As for the pattern of agroforestry between red Jabon, white Jabon and rice found only pests of A. hilaralis_with an attack percentage of 5\%. This shows that agroforestry cropping pattern could suppress pest attack in the plant of Jabon.

Key words: pest, red Jabon, white Jabon

\begin{abstract}
ABSTRAK
Jabon (Anthocephalus spp.) merupakan salah satu jenis tumbuhan lokal Indonesia yang berpotensi untuk dikembangkan dalam pembangunan hutan tanaman maupun untuk tujuan lainnya, seperti reklamasi lahan bekas tambang, penghijauan dan pohon peneduh, karena pertumbuhannya yang sangat cepat, kemampuan beradaptasinya pada berbagai kondisi tempat tumbuh, serta perlakuan silvikulturnya yang relatif mudah. Jenis ini juga diharapkan menjadi semakin penting bagi industri perkayuan di masa mendatang, terutama ketika bahan baku kayu pertukangan dari hutan alam diperkirakan akan semakin berkurang. Tanaman ini sudah lama dibudidayakan masyarakat hampir di seluruh wilayah Indonesia baik dengan pola tanam monokultur maupun campuran seperti agroforestri. Salah satu kendala dalam budidaya jenis ini yaitu adanya serangan hama defoliator. Penelitian ini bertujuan untuk mengidentifikasi jenis hama defoliator yang menyerang tegakan jabon merah (A. macrophyllus Roxb. Havil) dan jabon putih (A. cadamba Miq.) umur 8 bulan yang ditanam secara monokultur maupun agroforestri (dengan tanaman padi). Penelitian dilakukan pada Bulan Agustus sampai Desember 2014 di Desa Sumber Mekar Mukti dan Desa Sukatani, Kecamatan Tanjung Lago, Kabupaten Banyuasin, Provinsi Sumatera Selatan. Hasil penelitian menunjukkan bahwa jenis hama defoliator yang menyerang tegakan jabon merah yaitu Moduza procris Cramer (Lepidoptera : Nymphalidae) dengan persentase serangan sebesar $45,5 \%$. Sedangkan pada tegakan jabon putih yaitu Arthroschista hilaralis Walk dengan persentase serangan sebesar $86 \%$. Adapun pada pola agroforestri antara jabon merah, jabon putih dan padi hanya dijumpai serangan hama A. hilaralis dengan persentase serangan sebesar 5\%. Hal ini menunjukkan bahwa pola tanam agroforestri mampu menekan serangan hama pada tegakan jabon.
\end{abstract}

Kata kunci : hama, jabon merah, jabon putih 


\section{PENDAHULUAN}

Jabon (Anthocephalus spp.) merupakan salah satu jenis tumbuhan lokal Indonesia yang berpotensi untuk dikembangkan dalam pembangunan hutan tanaman maupun untuk tujuan lainnya, seperti reklamasi lahan bekas tambang, penghijauan dan pohon peneduh, karena pertumbuhannya yang sangat cepat, kemampuan beradaptasinya pada berbagai kondisi tempat tumbuh, serta perlakuan silvikulturnya yang relatif mudah.

Jabon merah (Anthocephalus macrophyllus Roxb. Havil) dan jabon putih (A. cadamba Miq.) termasuk dalam famili Rubiaceae. Tanaman ini merupakan jenis pohon yang memiliki prospek tinggi untuk hutan tanaman industri maupun hutan rakyat yang ada di Indonesia. Pertumbuhan tanaman ini relatif cepat, mampu beradaptasi pada berbagai kondisi tempat tumbuh, serta perlakuan silvikulturnya relatif mudah. Tanaman ini sudah lama dibudidayakan masyarakat hampir di seluruh wilayah Indonesia baik dengan pola tanam monokultur maupun campuran seperti agroforestri.

Pemanfaatan kayu jabon digunakan sebagai bahan bangunan nonkonstruksi, meubelir atau furniture, bahan kayu lapis atau plywood, papan, peti, korek api dan sebagainya. Pemanfaatan non kayu lainnya sebagai obat tradisional yaitu digunakan sebagai obat kumur dengan cara diekstrak terlebih dahulu. Daun segar dimanfaatkan oleh masyarakat sebagai pakan ternak. Kayu jabon merah bisa dimanfaatkan juga sebagai arang aktif. Arang yang dihasilkan dari jabon merah tidak memiliki bau dan tidak mengeluarkan asap atau percikan, namun nilai energi yang dihasilkan tergolong rendah yaitu $19.800 \mathrm{~kJ} / \mathrm{kg}$ (Halawane et al., 2011).

Salah satu kendala dalam budidaya jenis ini yaitu adanya serangan hama. Hal ini disebabkan sebagai suatu ekosistem yang homogen, kawasan hutan tanaman rentan terhadap berbagai kendala di antaranya serangan hama. Populasi tanaman hutan yang homogen akan mudah diserang dan berpotensi terjadi ledakan (outbreak) hama, baik di lapangan maupun di persemaian (Krisnawati et al., 2011).

Penelitian ini bertujuan untuk mengidentifikasi jenis hama defoliator yang menyerang tegakan jabon merah (A. macrophyllus Roxb. Havil) dan jabon putih (A. cadamba Miq.) umur 8 bulan yang ditanam secara monokultur maupun agroforestri (tumpang sari dengan tanaman padi).

\section{BAHAN DAN METODE}

\section{Tempat dan Waktu}

Penelitian dilakukan pada bulan Agustus sampai Desember 2014 di Desa Sumber Mekar Mukti dan Desa Sukatani, Kecamatan Tanjung Lago, Kabupaten Banyuasin, Provinsi Sumatera Selatan.

\section{Bahan dan Alat}

Bahan yang digunakan dalam penelitian ini adalah tegakan monokultur jabon putih, monokultur jabon merah, dan campuran (jabon merah-jabon putihpadi) dimana masing-masing tegakan berumur 8 bulan, dan kertas label. Sedangkan alat yang digunakan antara lain hand counter, kotak serangga, ice box, pinset, kamera, dan alat tulis.

\section{Metode}

\section{Monitoring Hama}

Kegiatan ini bertujuan untuk mengidentifikasi dan memonitor populasi hama pada tegakan jabon pola monokultur dan campuran. Kegiatan ini dilakukan dengan cara mengamati jenis hama dan tingkat serangan baik persentase dan intensitas serangan hama setiap seminggu sekali selama empat minggu.

Identifikasi hama dilakukan dengan mengumpulkan telur, ulat, pupa dan atau imago. Identifikasi dilakukan di Museum Zoologi, Pusat Penelitian 
Biologi, Lembaga Ilmu Pengetahuan Indonesia (LIPI), Bogor.

\section{Penghitungan persentase serangan dan tingkat kerusakan tanaman}

Persentase serangan hama $(\mathrm{P})$ dihitung dengan cara menghitung jumlah bibit yang terserang dalam suatu petak ukur, dibagi jumlah pohon yang terdapat dalam suatu petak ukur di kali $100 \%$.

$P=\frac{\text { Jumlah } \tan \text { aman yang terserang dalam suatu petak } u k u r}{\text { Jumlah seluruh } \tan \text { amandalam suatu petak } u k u r} \times 100 \%$

Penghitungan tingkat kerusakan tanaman (I) dilakukan menurut kriteria Unterstenhofer (1963) dalam Djunaedah (1994) dengan sedikit modifikasi (Tabel 1 dan Tabel 2). Adapun cara menghitung tingkat kerusakan tanaman dilakukan dengan menggunakan rumus di bawah ini.

$$
I=\frac{\sum\left(n_{i} \times v_{j}\right)}{Z \times N} \times 100 \%
$$

Keterangan :

I :Tingkat kerusakan tanaman

$\mathrm{n}_{\mathrm{i}} \quad$ :Jumlah pohon yang terserang dengan klasifikasi tertentu

$\mathrm{v}_{\mathrm{j}} \quad$ :Nilai untuk klasifikasi tertentu

$\mathrm{Z}$ :Nilai tertinggi dalam klasifikasi

$\mathrm{N}$ :Jumlah pohon seluruhnya dalam suatu petak contoh.

\section{HASIL DAN PEMBAHASAN}

\section{A. Jenis Hama dan Gejala Serangan}

Berdasarkan hasil penelitian menunjukkan bahwa ditemukan dua jenis hama yang menyerang tegakan jabon yaitu Moduza procris Cramer dan Arthroschista hilaralis Walk. Hama $M$. procris lebih menyerang tegakan jabon merah sedangkan A. hilaralis lebih menyerang tanaman jabon putih.

\section{M. procris}

$M$. procris merupakan serangga yang termasuk ordo Lepidoptera famili Nymphalidae. Serangga ini mempunyai tipe metamorfosis sempurna (holometabola), yaitu terdiri dari stadia telur, larva, pupa dan imago. Telur berbentuk agak bulat berwarna hijau kekuningan dan terdapat rambut-rambut halus seperti duri pada permukaannya (Gambar 1). Menurut Morrell (1948), telur $M$. procris berukuran $1 \mathrm{~mm}$, dengan lama fase telur 3.5 hari. Telur diletakkan kupu-kupu betina pada ujung daun tanaman inang yang terdapat bekas gigitan larva. Telur berwarna hijau kekuningan, agak bulat berbentuk kubah.

Larva M. procris berbentuk silindris (erusiform). Larva tua berwarna coklat tua sampai hitam. Pada ruas tubuh terdapat sejumlah duri (Gambar 2). Kepala berwarna coklat tua sampai coklat kemerahan dengan bercak-bercak merah. Pada kepala terdapat ciri khas yaitu adanya semacam tanduk bercabang pada bagian ujung. Larva memakan daun dengan cara menggigit dari ujung daun tanaman dan meninggalkan tulang daun.

Bentuk pupa berlekuk-lekuk dan terlihat seperti daun kering yang menggulung. Pupa berwarna coklat kekuningan atau coklat kehitaman. Bagian posterior pupa menempel pada batang atau daun dan terikat oleh benang sutra tipis (Gambar 3).

Imago yang baru keluar dari pupa sayapnya masih pendek, lunak, dan berkerut. Setelah beberapa saat, sayapsayap akan berkembang dan mengeras, pigmentasi akan terbentuk, dan imago siap melanjutkan perkembangannya. Kupu-kupu M. procris berwarna hitam, coklat kemerahan dengan spot putih.

Adapun gejala serangan pada tanaman jabon, larva serangga hama ini menyerang baik daun muda maupun daun tua dengan cara menggigit permukaan atas daun. Pada daun nampak gejala berbentuk lubang-lubang, lama kelamaan akan melebar dan mengakibatkan kerontokan daun. Gejala berat mengakibatkan tanaman menjadi gundul. 
Tabel 1. Klasifikasi tingkat kerusakan daun yang disebabkan oleh hama

\begin{tabular}{llc}
\hline \multicolumn{1}{c}{ Tingkat Kerusakan } & \multicolumn{1}{c}{ Tanda Kerusakan yang Terlihat pada Daun } & Nilai \\
\hline Sehat & - Kerusakan daun $\leq 5 \%$ & 0 \\
Ringan & - Kerusakan daun antara $5 \%<\mathrm{x} \leq 25 \%$ & 1 \\
Agak berat & - Kerusakan daun antara 25\%<x $\leq 50 \%$ & 2 \\
Berat & - Kerusakan daun antara $50 \%<\mathrm{x} \leq 75 \%$ & 3 \\
Sangat berat & - Kerusakan daun antara 75\%<x $\leq 100 \%$ & 4 \\
& - Pohon gundul/hampir gundul & \\
\hline
\end{tabular}

Tabel 2. Klasifikasi tingkat kerusakan batang yang disebabkan oleh hama

\begin{tabular}{llc}
\hline \multicolumn{1}{c}{ Tingkat Kerusakan } & Tanda Kerusakan Yang Terlihat pada Tanaman & Nilai \\
\hline Sehat & - Batang rusak $0 \%$ & 0 \\
Ringan & - Batang rusak antara $1 \%-20 \%$ & 1 \\
Agak berat & - Batang rusak antara $20,1 \%-40 \%$ & 2 \\
Berat & - Batang rusak antara $40,1 \%-60 \%$ & 3 \\
Sangat berat & - Batang rusak antara $60,1 \%-80 \%$ & 4 \\
Gagal & - Batang rusak di atas $80 \%$ & 5 \\
\hline
\end{tabular}

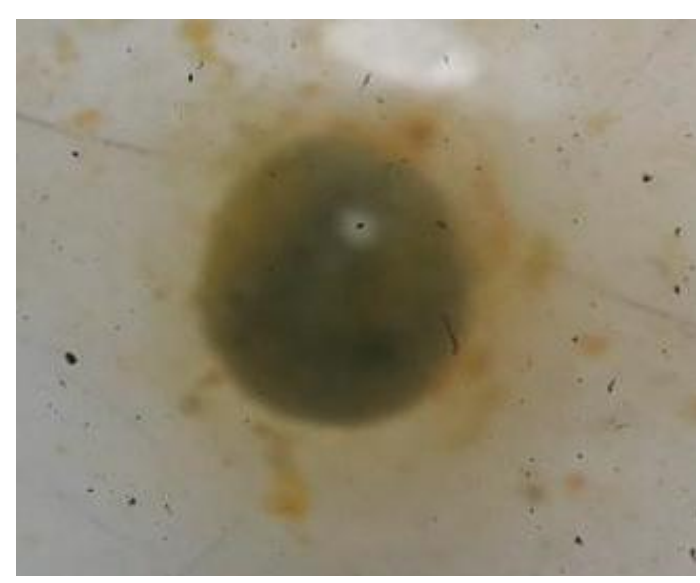

Gambar 1. Telur M. Procris

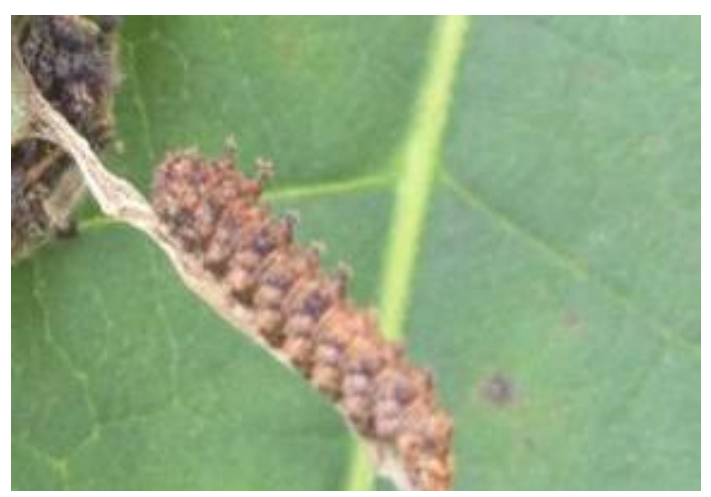

Gambar 2. Larva M. Procris 


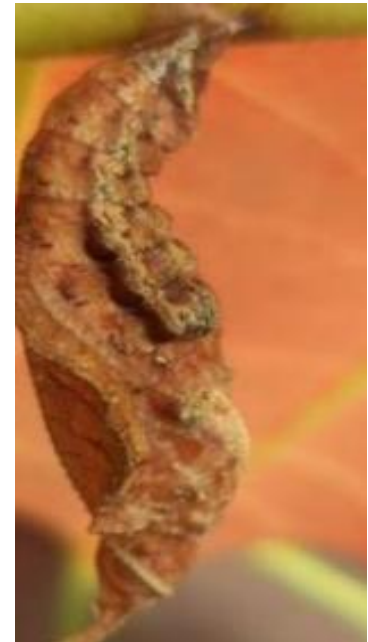

Gambar 3. Pupa M. Procris

\section{A. hilaralis}

A. hilaralis termasuk ke dalam ordo Lepidoptera, famili Pyralidae. $A$. hilaralis memiliki ukuran tubuh yang kecil dengan sayap depan memanjang dan berbentuk segi tiga dengan sayap belakang yang lebar, serta memiliki palpus labialis yang mencuat kedepan seperti moncong. Borror et al. (1976) menjelaskan bahwa famili Pyralidae merupakan famili terbesar ketiga dalam ordo Lepidoptera.

Telur A. hilaralis berbentuk bulat telur dan akan menetas setelah 2-3 hari diletakkan, dengan rata-rata waktu menetas 2.7 hari. Di West Bengal (India) periode telur berlangsung selama 3-4 hari (Thapa \& Bhandari, 1976).

Larva A. hilaralis memiliki tubuh berbentuk silindris dengan tiga pasang tungkai sejati pada bagian thoraks dan terdapat 4 pasang tungkai semu pada ruas ketiga hingga keenam abdomen (Gambar 5).

Pupa A. hilaralis termasuk ke dalam tipe obtekta. Bagian bakal antena, bakal mulut, bakal sayap dan bakal tungkai melekat pada tubuh dan tidak dapat dipisahkan. Perbedaan pupa jantan dan betina ditandai oleh adanya tonjolan pada sternum abdomen ruas terakhir pada pupa betina, sedangkan pada pupa jantan tidak terdapat tonjolan. Di West Bengal (India) periode pupa berlangsung

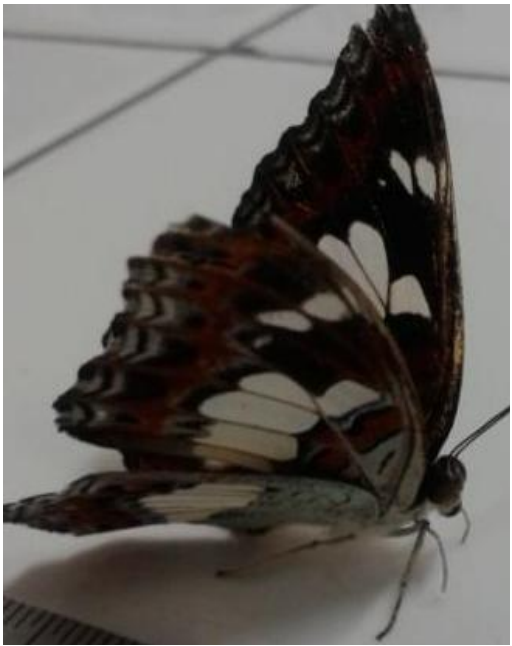

Gambar 4. Imago M. Procris

selama 5-7 hari (Thapa \& Bhandari, 1976).

Imago A. hilaralis berwarna hijau kebiruan dengan warna kuning oranye di sepanjang costa sayap (Gambar 6). Imago jantan dan betina memiliki ukuran tubuh yang tidak berbeda nyata. Lama hidup imago jantan lebih singkat dari imago betina. Rata-rata lama hidup imago jantan 4,0 hari, sedangkan imago betina 6,9 hari.

Adapun gejala serangan hama ini adalah terdapatnya lubang-lubang daun bekas gigitan larva. Awalnya larva menyerang tanaman dengan cara menggulung daun ke arah dalam kemudian larva akan menggigit daun. Serangan yang berat dapat mengakibatkan terjadi kerontokan daun dan tanaman menjadi gundul.

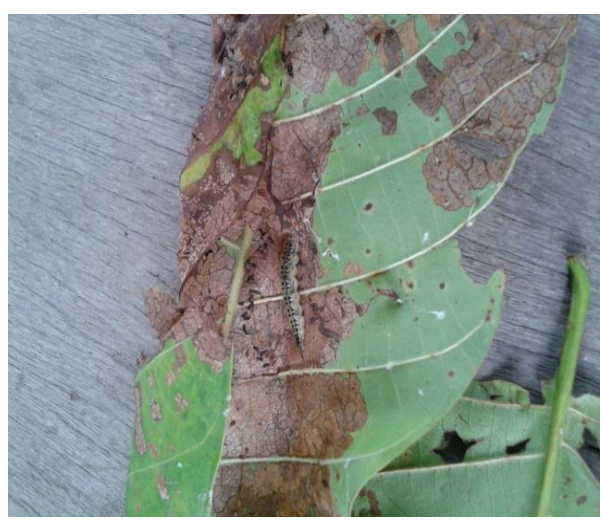

Gambar 5. Larva A. hilaralis 


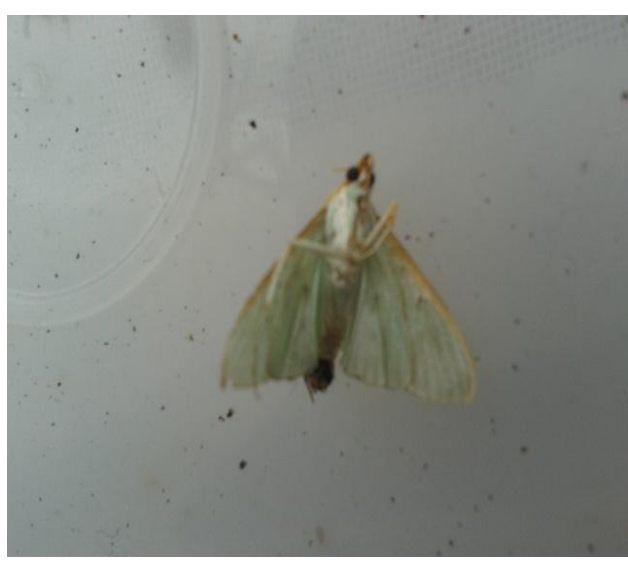

Gambar 6. Imago A. hilaralis

\section{B. Persentase dan Intensitas Serangan}

Berdasarkan pengamatan menunjukkan bahwa jenis hama defoliator yang menyerang tegakan jabon merah yaitu $M$. procris dengan persentase serangan sebesar $45,5 \%$. Sedangkan jenis hama yang menyerang tegakan jabon putih yaitu $A$. hilaralis dengan persentase serangan sebesar $86 \%$. Pada pola agroforestri antara jabon merah, jabon putih dan padi hanya dijumpai serangan hama $A$. hilaralis dengan persentase serangan sebesar 5\%. Hal ini menunjukkan bahwa pola tanam agroforestri mampu menekan serangan hama pada tegakan jabon. Dengan penerapan pola tanam secara agroforestri akan mengalihkan perhatian hama utama dalam menyerang tanaman inangnya. Selain itu penanaman secara agroforestri juga mampu menghambat siklus hidup hama tertentu. Oleh karena itu penanaman secara campuran seperti agroforestri sangat penting dilakukan dalam budidaya tanaman kehutanan mengingat sistem penanaman ini terbukti mampu mencegah dan menekan serangan hama.

Dengan ditemukannya jenis hama yang berbeda pada 2 jenis tegakan jabon yang berbeda, menunjukkan bahwa hama mempunyai preferensi makan terhadap tanaman inang yang diserangnya. Hal ini diduga karena kandungan nutrisi yang terdapat pada pakan mempunyai fungsi dan pemanfaatan yang berbeda-beda sesuai kebutuhan larva. Wali (2014) melaporkan bahwa jabon putih kandungan nutrisi penting seperti kadar air, protein, karbohidrat (serat kasar dan BETA-N), lignin, nitrogen dan kandungan lainnya dalam persentase yang banyak. Akan tetapi, persentase serat kasar dan lignin yang terdapat pada daun jabon putih. dalam jumlah yang banyak dapat menjadi faktor terjadinya antifeedant.

Selanjutnya, Wali (2014) melaporkan bahwa kandungan nitrogen yang tinggi pada jabon putih juga kurang berperan pada larva instar akhir, karena kandungan nitrogen lebih banyak dibutuhkan oleh larva instar awal daripada larva instar akhir. Disamping berfungsi sebagai sumber energi, lemak juga berperan sebagai struktur membran dan yang paling penting yaitu sebagai komponen kulit pelindung, karena salah satu jenis lemak dalam bentuk sterol merupakan prekursor hormon moulting ecdison (Bernays \& Chapman, 1994).

\section{KESIMPULAN}

1. Jenis hama defoliator yang menyerang tegakan jabon merah yaitu Moduza procris Cramer (Lepidoptera : Nymphalidae) dengan persentase serangan sebesar $45,5 \%$.

2. Jenis hama yang menyerang tegakan jabon putih yaitu Arthroschista hilaralis Walk dengan persentase serangan sebesar $86 \%$.

3. Pada pola agroforestri antara jabon merah, jabon putih dan padi hanya dijumpai serangan hama $A$. hilaralis dengan persentase serangan sebesar $5 \%$. Hal ini menunjukkan bahwa pola tanam agroforestri mampu menekan serangan hama pada tegakan jabon. 


\section{DAFTAR PUSTAKA}

Bernays, E.A. and Chapman, R.F. 1994. Host-plant selection by phytophagous insects. Chapman and Hall. New York.: International Thomson Publishing Company.

Borror, D.J, Delong, D.M. \& Triplehorn, C.A. 1976. An introduction to the study of insects. New York: New York.

Djunaedah, S. 1994. Pengaruh perubahan lingkungan biofisik dari hutan alam ke hutan tanaman terhadap kelimpahan keragaman famili serangga dan derajat kerusakan hama pada tegakan jenis Eucalyptus uerophylla, E. deglupta dan E. pellita .Tesis. Bogor : Institut Pertanian Bogor.

Halawane, J.E., Hidayah, H.N. \& Kinho, J. 2011. Prospek pengembangan jabon merah (Anthocephalus macrophyllus Roxb. Havil) solusi kebutuhan kayu masa depan. Manado: Balai Penelitian dan Pengembangan Kehutanan Manado.
Krisnawati, H, Kallio, M. \& Kanninem, M. 2011. Anthocephalus cadamba Miq. Ekologi, Silvikultur, dan Produktivitas. Bogor: CIFOR.

Morrell, R. 1948. Notes on the larvae of some common Malayan butterflies. Malay Nat J. 3(2): 18.

Thapa, R.S \& Bhandari, R.S. 1976. Biology, ecology and control of Kadam defoliator, Arthroschista hilaralis Walk. (Lepidoptera : Pyralidae) in plantation in West Bengal. Indian For. 102 (6): 333-401.

Wali, M. 2014. Moduza procris Cramer (Lepidoptera : Nymphalidae) pada Jabon Merah dan putih (Anthocephalus spp.) perkembangan dan preferensi makan. Tesis. Bogor: Institut Pertanian Bogor. 